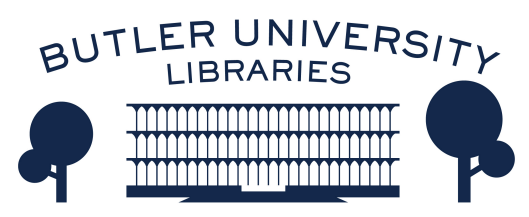

Journal of Hindu-Christian Studies

Volume 8

Article 4

January 1995

\title{
The Nature and Authority of Scripture: Implications for Hindu- Christian Dialogue
}

Anantanand Rambachan

Follow this and additional works at: https://digitalcommons.butler.edu/jhcs

Part of the Religion Commons

\section{Recommended Citation}

Rambachan, Anantanand (1995) "The Nature and Authority of Scripture: Implications for Hindu-Christian Dialogue," Journal of Hindu-Christian Studies: Vol. 8, Article 4.

Available at: https://doi.org/10.7825/2164-6279.1109

The Journal of Hindu-Christian Studies is a publication of the Society for Hindu-Christian Studies. The digital version is made available by Digital Commons @ Butler University. For questions about the Journal or the Society, please contact cbauman@butler.edu. For more information about Digital Commons @ Butler University, please contact digitalscholarship@butler.edu. 


\title{
The Nature and Authority of Scripture : Implications for Hindu-Christian Dialogue
}

\author{
Anantanand Rambachan \\ St Olaf College
}

IN A THOUGHTFUL series of reflections on the future of Hindu-Christian Dialogue, Klaus Klostermaier observes that there are "few Hindus who are interested in (contemporary) Christian theology, and there are fewer still who have a desire to enter into dialogue with their Christian counterparts". ${ }^{1}$ Others have noted that, with few notable exceptions, the initiatives for dialogue in recent times have been from the Christian side. $^{2}$ In an earlier study, I suggested, briefly, a few possible reasons for this lack of interest on the Hindu side. The memories of colonialism and its association with aggressive Christian missionary activity, misrepresentation of other religions, and the lack of genuine interest in the study and understanding of these traditions are not easily erased. There are still barriers of mistrust to overcome. ${ }^{3}$ I interpreted this lack of interest also as a reflection of certain popular Hindu attitudes towards religious pluralism. The famous Rgveda text, "One is the Truth, the sages speak of it differently" (I.64.46), is often employed to explain away doctrinal differences as merely semantic ones. The point of this text, as its context makes quite clear, is not really to dismiss the significance of the different ways in which we speak of the One or to see these ways as equally valid. The text is really a comment on the limited nature of human language. Such language must by nature be diverse in its attempts to describe that which is One and finally indescribable. The text, however, is widely cited in ways that seem to make interreligious dialogue redundant.
Klostermaier laments the trend in contemporary Christianity and Hinduism "to dismiss the intellectual approach to religion as irrelevant and to cultivate only its emotional and pragmatic sides". Arguing that intellectuals and scholars must be allowed to play a more vital and central role in the development of these traditions, Klostermaier affirms that Hindu-Christian dialogue

must recover the intellectual substance of Hinduism and Christianity and must contribute actively to the ongoing search for truth/reality in all spheres of life. The intellectual dimension of life has not lost its importance in our time. ${ }^{4}$

The loss of intellectual vigour in contemporary Hinduism is a matter of deep concern and the causes are many and complex. There are also serious implications for the Hindu interest in dialogue with Christians and for the nature of such dialogue. In this article, I want to identify what I perceive to be one major cause for the erosion of intellectual life in Hinduism and its divorce from spirituality. I wish to reflect also on the significance of this for Hindu-Christian dialogue.

It is my contention that the decline in the significance of Vedic exegesis and the reinterpretation of the authority of the Vedas in contemporary times vis-à-vis personal experience are connected closely with the weakening of scholarship in Hinduism and its lack of interest in vigorous dialogue with Christianity. It is not possible here to describe in detail and to trace the historical roots of this process of reinterpretation; I 
have already attempted this elsewhere. ${ }^{5}$ I will, however, highlight some of the salient and relevant historical developments and draw attention to their significance for Hindu-Christian dialogue.

The Western impact on India in the eighteenth century had far-reaching implications for almost every aspect of Indian life and served as a catalyst for the cultivation of attitudes of rational inquiry and criticism. The earliest Hindu reformer to reflect the impact of the West in his thinking about Hinduism is the Brahmo Samaj leader, Rammohun Roy. While Roy's attitude to the authority of the Vedas had an element of ambiguity about it, even among his own followers, it is quite clear that his approach to the texts was different from orthodox Pūrva Mìmāmsa exegetes or from the Advaita Vedānta interpreter, Sankara. Roy applied an extrascriptural criterion of "true" religion in his evaluation of the worth of any text, including the Vedas. He did not see religious truth as being limited to the texts of the Vedas or see the Vedas as being indispensable for our knowledge of God. The texts themselves and not only their interpretations, he argued, must be subject to rational analysis.

What I perceive as a watershed in the attitude of contemporary Hindu interpreters to the authority of the Vedas occurred under the leadership of Roy's successor, Debendranath Tagore (1817-1905). The change was initiated as a consequence of a debate sparked by the conversion to Christianity of Umesh Chandra Sarkar and his wife. Sarkar was a student at Alexander Duff's school, and there was vigorous opposition to the school. Duff responded with a challenge to the doctrines of the Brahmo Samaj, questioning in particular the belief in Vedic infallibility. ${ }^{6}$ The Samaj initially defended the doctrine, but this stirred a great degree of unease in its ranks. In an effort to resolve this issue, Debendranath Tagore sent four brahmin youths to Benares to study the Vedas. His own visit to the city in 1847 was partly in pursuit of the same inquiry. Finally, the doctrine of Vedic infallibility was abolished in $1850 .^{7}$ Perhaps the main reason for Tagore's rejection of the doctrine of infallibility was his refusal to accept passages in the Upanishads affirming the identity of atman and brahman. He chose to see brahman as lord and regulator of the universe and to see the ätman as dependent on brahman for its existence. ${ }^{8}$

From that time onwards, the nonauthoritative status of any text became enshrined in the creed of the Brahmo Samaj. Nature and intuition took the place of scripture as twin sources of knowledge. The basis of Brahmoism became "the pure heart filled with the light of intuitive knowledge". Tagore himself became increasingly reliant on personal intuition as his authority and the notion of divine command (ädesa) assumed a significant role in his life.

Tagore's successor to the leadership of the Brahmo Samaj, the charismatic Keshub Chandra Sen (1838-1884), rejoiced in the rejection of Vedic infallibility. He saw it as a grand step in the evolution of the Samaj and its embrace of monotheism which

\section{was not confined to Hindoo books, to the scriptures of their own countrymen, but was to be found in human nature in all the races and tribes and nations of the world. ${ }^{9}$}

Keshub propagated a general theory of revelation in which he included nature, history, by which he means "great men", and inspiration. He clearly emphasized inspiration as the most direct and significant form of revelation. He described it as

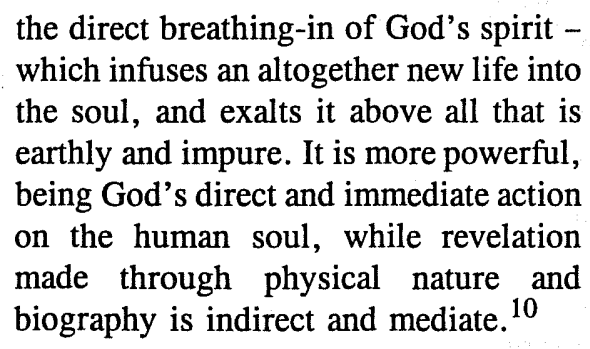

Sen went much further than Tagore in his denunciation of what he regarded to be 
doctrine and dogma, and in his unfavourable comparison of these with the "fire of inspiration". Doctrine and dogma which relate to intellectual cognition, reasoning and logical thought were cold and lifeless and had nothing to do with the attainment of salvation. He spoke of direct perception as the only reliable, conclusive and self-evident means of gaining spiritual knowledge and saw this perception as affirmed in the Upanishads.

\begin{abstract}
No expression is more frequently used in the Upanishads than the "perception" of God (darśan). It appears that Hindu sages, not content with intellectual conceptions of the Almighty or abstract contemplation of certain Divine attributes, sought earnestly and indeed successfully, to behold the Supreme Spirit directly and to apprehend Him as a distinct and vivid reality in their inner consciousness. ${ }^{11}$
\end{abstract}

Towards the end of his life, Sen, like Debendranath Tagore before him, gave increasing prominence to the authority of divine command (ádesa) and claimed to have received a special revelation and dispensation from God. The significance of scriptural revelation was reduced by his claim that the texts of this New Dispensation (Nava-Vidhan) included "the whole of science, physical, metaphysical and moral and also the science of religion".

At the time of Keshub's death in 1884, the centre of religious attention in Calcutta had already shifted to Ramakrishna (18361886) who had taken up residence in the Kālī temple at Dakshineshwar. Primarily through Vivekananda and the Ramakrishna Mission founded in 1897, Ramakrishna, like the Brahmo Samaj, has exerted significant influence on the character of contemporary Hindu attitudes to scriptural authority. While Ramakrishna's background was different from that of the Brahmo Samaj leaders in that he was virtually unexposed to westernizing influences, he concurred with them in his disdain for scripture and in his championing of personal experience.
Ramakrishna possessed a deep aversion to formal learning and education. Learned persons were likened by him to kites and vultures, which soar to great heights in the sky but whose eyes are forever focused on the decaying carcasses below. They were also described as similar to foolish people in an orchard who count the leaves and fruit and argue to estimate their value instead of plucking and relishing the juicy fruit. Reason and the intellectual life received little attention or recognition in his teachings.

Ramakrishna confessed scepticism about the value of scriptural study. The scriptures are diluted, containing, as he puts it, a "mixture of sand and sugar", difficult to distinguish and separate. They are of no use in conveying the feeling of God:

This feeling is something very different from book-learning. Books, scriptures, and science appear as mere dirt and straw after the realization of God.

Like with Keshub Chandra Sen, the direct vision of God was the main theme of his instruction. It was the only form of verification:

But seeing is far better than hearing. Then all doubts disappear. It is true that many things are recorded in the scripture; but all these are useless without the direct realization of God. ${ }^{12}$

Swami Vivekananda (1863-1902), the foremost disciple of Ramakrishna, has, more than any other Hindu in recent times, influenced the popular understanding of Hinduism in India and abroad. There is very little in modern Hindu, particularly Vedānta, apologetic writing that does not carry the imprint of Vivekananda's influence. His attitude to scriptural authority was shaped by the teachings of Ramakrishna, but also by the stand of the Brahmo Samaj in whose circles he was active as a youth. $\mathrm{He}$ developed the suggestions and outlines from these sources into an elaborate rejection of the necessity for scripture. 
Vivekananda followed his teacher, Ramakrishna, in attributing a low value to scriptures and in upholding the supremacy of personal experience. The adequacy of scriptures is compared to the utility of a map to a traveller, before visiting a country. ${ }^{13}$ The map, according to Vivekananda, can create only curiosity for first-hand knowledge of the place and can communicate only a vague conception of its reality. Maps are in no way equivalent to the direct knowledge of the country, gathered by actually being there.

Vivekananda understands the Vedas to be records of the spiritual discoveries of others and the methods by which such discoveries have been made. These findings, however, have no validity unless they are personally rediscovered by each person:

There are certain religious facts which, as in external science, have to be perceived and upon them religion will be built. Of course, the extreme claim that you must believe every dogma of a religion is degrading to the human mind. The man who asks you to believe everything, degrades himself, and, if you believe, degrades you too. The sages of the world have only the right to tell us that they have analysed their minds and have found these facts, and if we do the same we shall also believe, and not before. That is all there is in religion. ( $C W, 2: 163)$

The proof of the truth of the Vedas is the direct knowledge of the individual, not the fact of its embodiment in any text. The individual must verify the text and this verification is likened to ordinary direct perception.

The proof, therefore, of the Vedas is just the same as the proof of this table before me, pratyaksa, direct perception. This I see with the senses, and the truths of spirituality we also see in a superconscious state of the human soul. (CW, 3:253)

The imperative, therefore, for Vivekananda, is that everyone should become a rsi. The chief characteristic of $r s i$ status is the possibility of a direct apprehension of truth. The possibility and requirement of every individual to become an $r s i$ is one of the important points of contrast that Vivekananda emphasized between Hinduism and other religious traditions. In the latter, he claims, insight is limited to a few select individuals through whom truth is made available to the many.

Truth came to Jesus of Nazareth, and we must all obey him. But the truth came to the rsis of India - the mantradrastās - the seers of thought - and will come to all rsis in the future, not to talkers, not to book-swallowers, not to scholars, not to philologists, but to seers of thought. ( $C W, 3: 283$ )

Vivekananda often asserted that only in becoming a rsi does one understand the scripture properly. His argument appears to be that as products and records of direct perception, these texts were not written for the intellect, or for understanding through a process of rational inquiry and analysis. They become meaningful only when one has lifted oneself to the same heights of perception. At that point, however, they are useful only to the extent that they confirm what one has known directly $(C W, 4: 165$, $7: 85,89$ ). An opinion like this seems to deprive the scriptures from having even the preliminary worth of a map.

Scriptural analysis is described by Vivekananda as intellectual opium eating (see $C W, 1: 45,4: 168$ ). Scriptures are specified by him as unsatisfactory theoretical religion and included among the nonessentials of religion. Among other nonessentials he listed doctrines, dogmas, rituals, temples, images and forms.

S. Wesley Ariarajah identifies four different types of interreligious dialogue, each with its unique contribution to make. ${ }^{14}$ Dialogue of life is an encounter which takes place in the course of everyday life among people of different traditions who live in the same community. There is no conscious or explicit articulation and 
exchange of religious belief. Such explicit exchange of beliefs and perspectives is a characteristic of the dialogue of discourse. In the dialogue of spirituality, participants seek "to go beyond words to encounter the other at the level of the heart". It attracts those "who feel that the essential unity of humanity cannot be expressed in words, but must be celebrated in worship and meditation". Finally, the dialogue of action is characterized by cooperation among people of different faiths for the attainment of desirable ends of their common existence such as peace, justice, protection of the environment, human rights etc.

While acknowledging the various forms of interreligious dialogue, it appears to me that what Ariarajah calls the dialogue of discourse will continue to be one of its necessary and vital forms. While not prominent in the other forms, it seems to be implied in them. The sharing of thought and reflection, the understanding of the scope and limits of reason and language in other traditions, and the mutual enrichment which comes from exposure to each other's wisdom (jñāna) are facets of dialogue which, if engaged in with commitment, humility and a passion for truth, can never become "ivory tower" intellectualism. Such dialogue needs to find a prominent place in the meeting of Hinduism and Christianity.

The decline of intellectual vigour in any tradition through the denigration of reason and the intellect will be reflected in the quality of its interest in other traditions and in the kind of interreligious dialogue in which it desires to engage. The championing in contemporary Hinduism of personal experience over the authority of scripture, which I have briefly traced in this essay, has contributed to the divorce of scholarship from spirituality. Examples of scholarship without religious commitment and religious commitment lacking the self-critical insights of scholarship abound. The creative combination of scholarship and spirituality is rare in modern Hinduism. Their disconnection limits the quality of the Hindu dialogue with Christianity. The dialogue of discourse is most enriching when it occurs among participants whose lives reflect the integration of both.

The divorce to which I am referring can be illustrated by highlighting the classic approach of Sankara or Ramanuja. For Sankara, the Vedas are the definitive and unique source of our knowledge of brahman, the gain of which leads to the discovery of moksa. The Vedas are a valid source of knowledge in the form of words (śabdapramāna) and saving knowledge depends on the proper comprehension of the meaning of these words. Scriptural learning and exegesis therefore become very important along with such disciplines as grammar and etymology that aid interpretation. Proper principles for arriving at the meaning of the text are important. ${ }^{15}$

The acceptance of the Vedas as an authoritative source of knowledge did not mean the abandonment of a very important role for reason. Reason is important for deciding between different interpretations of passages and for reconciling conflicting ones. Reason also plays an important role in assessing and responding to rival views. Sankara obviously takes differences of doctrine very seriously and in responding to the claims of rival systems which do not accept the authority of the Vedas, he is constrained to demonstrate the validity of Advaita on the basis of the reasonableness of its propositions.

The decline of the significance of the Vedas as a pramāna and its characterization as second-hand religion has contributed to the devaluing of scriptural scholarship. Its study, exegesis and interpretation are not of utmost significance. Vivekananda contemptuously dismisses scriptural scholarship as an activity at the theoretical and intellectual level. With an emphasis in contemporary Hinduism on the gain of knowledge through the transcendence of reason and not on its mediation, reason, argument and intellectual activity, all important qualities of interreligious dialogue, 
assume more of an obstructive character. There is an impassioned derogation and belittlement of the human intellect in Vivekananda, the leading Neo-Vedānta interpreter, which is not at all found in his classical predecessors:

The intellect is only the street-cleaner, cleansing the path for us, a secondary worker, the policeman; but the policeman is not a positive necessity for the workings of society. ( $C W, 2: 306)$

Paradoxically, it would seem that where the Vedas are upheld as a valid means of knowledge, reason has a more positive role to play in clarifying, explaining and defending its propositions. Where the attempt is made, on the other hand, to supersede the necessity for faith in the scripture in the interest of being more rational, reason becomes almost insignificant.

The rejection of the primary authority of scripture, the derision of scholarship, the ridicule of dogma and doctrine and the belittling of reason, which we see in so many modern interpreters of Hinduism, have other important implications for HinduChristian dialogue. Perhaps most important is the tendency to overlook the significance of doctrinal differences. Because conclusive insight is understood to be gained through an experience which transcends reason, interpreters like Vivekananda are able to dismiss what they perceive to be preoccupation of the rational mind. It is only by overlooking and dismissing the importance of different doctrinal claims that one can so easily assert, as many Hindus do, that all paths lead to the same goal. Such scant regard for differences of doctrine is often frustrating for many Christians who engage with Hindus in dialogue.

I do not wish to deny the vital role of the experiential dimension in the human search for truth or to claim that it is without significance in the Hindu tradition. Sankara, himself, at various points in his commentary on the Brahma-sūtra acknowledges this role. ${ }^{16}$ While Sankara, as I believe, acknowledges the ultimacy of scriptural revelation for our knowledge of the absolute, his understanding of the relationship between scripture and personal experience (anubhava) is dynamic and creative. It offers scope for vigorous life of the intellect by preserving for it a necessary role in the spiritual quest. By being more faithful to the Upanisadic ideal of the unity of learning (śrotriyam) and commitment to spiritual truth (brahmanistham) it offers a more promising and rewarding model for Hindu dialogue with Christianity and other religions. The complete subordination, on the other hand, of scriptural revelation to the authority of personal experience and the associated vilification of reason, the role of the intellect, discussion and language have sadly engendered scepticism about the worth of dialogue in which these have a prominent role. The devaluation of learning and intellectual skills in a prominent heroic interpreter of Hinduism, like Vivekananda, must not go unchallenged.

Since the latter half of the 1960 s, the Hindu population of the United States has been growing steadily. Until that time, the doors of welcome were virtually shut to immigrants from Asia. The Chinese exclusion act of 1882 was applied broadly to include all people of Asian origin. In 1965, a new immigration law, initiated by John $\mathrm{F}$. Kennedy, abolished quotas based on national origins and opened the country to immigrants from India. Today there are lively and flourishing communities of Hindus in most of the major cities of North America and temple construction has rapidly followed the establishment of such communities. Hindus are prominently among those whom W. C. Smith described as "our neighbours, our colleagues, our competitors, our fellows". 17

The context of interrelated living offers fruitful opportunities for the "dialogue of life" between Hindus and Christians and this is clearly taking place. I think that most Hindus in North America will easily identify occasions and moments in their lives when 
they had to articulate some aspect of their faith and practice to people of other religions. Hindus, on the whole, usually embrace the opportunity to do this. Our interrelated lives in communities of diversity will also require of us more engagement in the "dialogue of action" through which we will be called upon to work with others for the advancement of mutual interests. While there are many groups in North America whose beliefs and practices are influenced by elements of Hinduism, the "dialogue of spirituality" which Ariarajah describes as involving participation in each other's worship and meditation is still exceptional for Hindus. There is only one Hindu-based organization, of which I am aware, The International Society of Krishna Consciousness in West Virginia, which prominently promotes dialogue of this kind. Ariarajah points to the concerns which many people have about the possibility of meaningfully entering the worship of another tradition and fears of uncritical syncretism.

The dialogue of discourse between Hinduism and Christianity in North America is lacking both in frequency and depth and in this essay I have offered another reason for what many have discerned to be the lack of Hindu interest and initiative for such dialogue. The questioning of uncritical attitudes about the supremacy of personal experience, and the recovery of its existing but overshadowed traditions of vibrant learning and spirituality seem to me to be a necessary condition for fruitful dialogue of discourse between both traditions. Modern Hindu commentators have not only upheld the authority of personal experience but they have affirmed this to be the uniqueness of Hinduism. I am convinced that the affirmation of a more creative relationship between revelation, reason and experience will reveal many more exciting areas of common interest for discussion between our two religions.

\section{Notes}

1. Klaus Klostermaier, "The Future of HinduChristian Dialogue" in Harold Coward (Ed.), Hindu-Christian Dialogue. Maryknoll: Orbis Books, 1989, p.265.

2. See Harold Coward, "Hindu-Christian Dialogue: A Review", Hindu-Christian Studies Bulletin 1 (Autumn 1988), pp.1-5.

3. See Anantanand Rambachan, "Religious Pluralism: A Hindu Perspective", Current Dialogue 17 (December 1989), pp.25-7.

4. Klostermaier, "The Future of HinduChristian Dialogue" p.269.

5. Anantanand Rambachan, The Limits of Scripture: Vivekananda's Reinterpretation of the Authority of the Vedas. Honolulu: University of Hawaii Press, 1994. See Chapter 1.

6. See Sivanath Sastri, History of the Brahmo Samaj, 2nd ed. Calcutta: Brahmo Samaj, 1974, p.63.

7. It is unfortunate that there are no records of the details of the argument on both sides. Such records would have clarified the concerns of the Brahmo Samaj about the authority of the Vedas.

8. See S. K. Das, The Shadow of the Cross: Christianity and Hinduism in a Colonial Context. Delhi: Munshiram Manoharlal, 1974, pp.70-1.

9. K. C. Sen, "The Living God in England and India" in Discourses and Writings. Calcutta: Brahmo Tract Society, 1904, p.149.

10. K. C. Sen, "Great Men" in S. D. Collet (Ed.) Lectures and Tracts by Keshub Chunder Sen. London: Strahan, 1870, p.88.

11. K. C. Sen, "Primitive Faith and Modern Speculations" in Discourses and Writings, p.46.

12. See Mahendranath Gupta, The Gospel of Ramakrishna. Swami Nikhilananda (Trans.) New York: Ramakrishna-Vedanta Centre, 1977, pp.543, 645-6, 476.

13. See The Complete Works of Swami Vivekananda (CW). 8 vols. Calcutta: Advaita Ashrama, 1964-1971, 1: 185-6. (Documentation is hereafter given in the text).

14. See S. Wesley Ariarajah, "Pluralism and Harmony", Current Dialogue 25 (December 1993), 17-19. 
The Nature and Authority of Scripture 27

15. For a discussion of the method of Sankara see Anantanand Rambachan, Accomplishing the Accomplished: The Vedas as a Source of Valid Knowledge in Śañkara. Honolulu: University of Hawaii Press, 1991.
16. See, for example, his commentary on Brahma-sūtra I.i.2.

17. W. C. Smith, The Faith of Other Men. New York: Harper and Row, 1972, p.11. 